\title{
Okadaic acid-induced apoptosis in malignant glioma cells
}

\author{
Bimal G. Rami, M.D., LaWrence S. Chin, M.D., Barbara E. Lazio, M.D., \\ and Satyendra K. Singh, Ph.D.
}

Department of Neurosurgery and Greenbaum Cancer Center, University of Maryland School of Medicine, Baltimore, Maryland

\begin{abstract}
Object. Okadaic acid (OA), a potent protein phosphatase inhibitor, has been known to induce apoptosis in a variety of cell types. The authors attempted to characterize further this model by identifying proteins involved in this form of programmed cell death.

Methods. Cellular proliferation was assessed using a colorimetric nonradioactive proliferation assay and cell counts. Apoptosis was determined by fluorescent microscopy. Activation of the mitogen-activated protein kinase (MAPK) pathways was determined by immunoprecipitation of extracellular signal-regulated kinase (ERK), c-Jun-N-terminal kinase (JNK), and p38 followed by in vitro kinase assays. Western blot analyses were conducted to show inhibitory- $\mathrm{B}$ (IкB) phosphorylation and degradation as well as Bax upregulation. The binding of nuclear factor $-\kappa \mathrm{B}(\mathrm{NF} \kappa \mathrm{B})$ was shown by electrophoretic mobility shift assay.

Okadaic acid induced cell death in T98G human malignant cell lines (50\% inhibiting concentration $=20-25 \mathrm{nM})$. In T98G cells YO-PRO fluorescent staining was identified, thus indicating an apoptotic mechanism with a smaller percentage of cells undergoing necrotic cell death. Additionally OA induced JNK and MAPK activities in a time-dependent manner, increased the expression of Bax, and increased IкB phosphorylation and $\mathrm{NF} \kappa \mathrm{B}$ activation. There was a temporal correlation between these subcellular events and the detection of apoptosis morphology in glioma cells.

Conclusions. The authors believe that OA acts by blocking dephosphorylation events, thus activating apoptotic path-

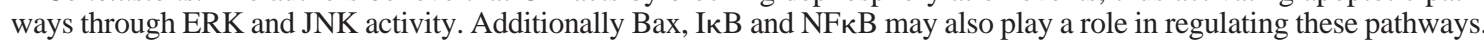

\section{Key WordS • apoptosis • Bax • glioma • inhibitary- $\mathrm{B}$ ・ c-Jun-N-terminal kinase • okadaic acid}

Apoptosis is a complex process of great importance to normal cell function and development. ${ }^{6}$ Deregulated apoptosis has been implicated in a number of pathological disorders resulting in increased cell survival or excessive cell death. ${ }^{39}$ Regulation of the intracellular pathways responsible for maintaining the proliferation and apoptotic signals within the cell are poorly understood. Normal and neoplastic cells respond to extracellular stimuli through signal transduction cascades from the plasma membrane to the nucleus..$^{20}$ The MAPK family, which includes extracellular signal regulated kinase ERK, p38, and JNK, has been shown to transmit both proliferative and apoptotic signals. ${ }^{16,24}$ Induction of JNK and p38 is observed in growth factor-deprived PC-12 cells that undergo apoptosis, an effect that is prevented by transfection of a dominant negative JNK construct. ${ }^{45}$ Protein phosphatases have

\footnotetext{
Abbreviations used in this paper: EMSA = electrophoretic mobility shift assay; ERL = extracellular signal-regulated kinase; IC50 $=50 \%$ inhibiting concentration; I $\mathrm{B}=$ inhibitory- $\kappa \mathrm{B} ; \mathrm{JNK}=$ $\mathrm{c}$-Jun-N-terminal kinase; MAPK $=$ mitogen-activated protein kinase; MTS = 3-(4,5-dimethylthiazol-2-yl)-5-(3-carboxymethoxyphenyl)-2-(4-sulfophenyl)-2H-tetrazolium; NFKB = nuclear factor$\kappa \mathrm{B} ; \mathrm{OA}=$ okadaic acid; $\mathrm{PBS}=$ phenazine methosulphate; $\mathrm{PP}=$ protein phosphatase; $\mathrm{SD}=$ standard deviation.
}

been shown to play an integral role in the regulation of protein kinase signal transduction in multiple human cell lines. ${ }^{1,28,47}$ Therefore, we hypothesized that these PPs may also be of importance in apoptotic signal transduction in glioma cells.

The transcription factor $\mathrm{NF}_{\kappa} \mathrm{B}$ contributes to the cellular response to diverse stimuli including cytokines, ionizing ration, and reactive oxygen species. ${ }^{42}$ Regulation of $\mathrm{NF} \kappa \mathrm{B}$ occurs through an inhibitory molecule, I $\mathrm{B}$, that binds noncovalently to NFKB and prevents its translocation into the nucleus. ${ }^{2}$ When the cell senses the appropriate external stimulus, IкB is phosphorylated by a recently identified kinase and then degraded, thus releasing NFKB to the nucleus. ${ }^{13}$ The effect of NFKB on apoptosis is unclear; the authors of several recent investigations have shown that it plays a protective role against tumor necrosis factor- $\alpha$-induced apoptosis. . $^{3,27,30,40,43}$

The culminating stages of apoptosis require the function of proteases that degrade cellular ultrastructure and nucleic acids. The cysteine proteases, interleukin- $1 \beta$-converting enzyme and CPP-32, cleave selectively at aspartate residues and are members of the caspase family of proteins. ${ }^{6,38}$ Caspases have recently been shown to activate during chemotherapy-induced apoptosis in tumor cells. ${ }^{23,33,51}$ In addition, stable transfection of an inducible 
interleukin-1 $\beta$-converting enzyme construct into a glioma cell line causes and apoptotic cell death. ${ }^{50}$

The caspases are homologous to the nematode Caenorhabditis elegans death gene ced-3, which may be counteracted by expression of $c e d-9$ and can substitute for its function in C. elegans ${ }^{41}$ Coimmunoprecipitation experiments involving Bcl-2 led to the discovery of Bax, a protein that promotes apoptosis. ${ }^{11,32,48,49}$ Excess Bcl-2, however, neutralizes Bax by forming heterodimers, thus resulting in suppression of apoptosis. It has been proposed that the relative intracellular levels of Bax and Bcl-2 function as the cellular "rheostat" that determines whether apoptosis will occur. ${ }^{31}$

Okadaic acid is a membrane-permeable $\mathrm{C}_{38}$ polyether fatty acid that inhibits serine/threonine PP1 and PP2A. ${ }^{35}$ Okadaic acid induces apoptosis in several tumor cells but has also been demonstrated to act as a tumor promoter similar to phorbol esters. ${ }^{14,17,22,29,36,37}$ Although there is evidence that $\mathrm{OA}$ is a potent in vitro and in vivo activator of NFкB DNA binding, ${ }^{34,46}$ this has never been studied in glioma cells. In this report, we describe OA-induced cell death in malignant glioma cell lines. We focus on the T98G cell line, which has been extensively studied in our laboratory. ${ }^{7-9}$ Our data suggest that PPs play a critical role by attenuating the apoptotic pathway signaled by either ERK or JNK activity. We also show that OA causes the activation of NFKB and Bax upregulation.

\section{MATERIALS AND METHODS}

\section{Cell Culture}

Stock cultures of T98G cells were obtained from American Type Culture Collection (Rockville, MD) and cultured in Eagle minimum essential medium supplemented with both $10 \%$ fetal bovine serum (Biofluid, Rockville, $\mathrm{MD})$ and glutamine $(2 \mathrm{mM})$. Cells were grown at $37^{\circ} \mathrm{C}$ in a humidified incubator with $5 \% \mathrm{CO}_{2}$. The proliferative rate for all three cell lines is similar.

\section{Cell Counting Procedures}

The number of living cells was assessed using the colorimetric nonradioactive proliferation assay, CellTiter 96 (Promega, Madison, WI), consisting of MTS (Owen reagent; $2 \mathrm{mg} / \mathrm{ml}$ ) combined with the electron coupling reagent, phenazine methosulphate $(0.92 \mathrm{mg} / \mathrm{ml})$. Cells were plated in 96-well microtiter plates for 48 hours. Immediately before use, the MTS and phenazine methosulphate solutions were combined, 20:1, and $20 \mu \mathrm{l}$ was added to each well and allowed to incubate at $37^{\circ} \mathrm{C}$ for 4 hours. The conversion of MTS to formazan was stopped by addition of $25 \mu \mathrm{l}$ of $10 \%$ lauryl sulfate, and formazan dye was quantified using an enzyme-linked immunosorbent assay plate reader at $490 \mathrm{~nm}$. Standard curves were determined to ensure correlation between cell number and absorbance. Proliferation curves were plotted as absorbance units \pm SD compared with log drug concentration, and IC50 was estimated by fitting the data in points to a four-parameter nonlinear regression curve by using Prism (Version 2.0; GraphPad Software, San Diego, CA). ${ }^{9}$

To confirm the MTS results, cell count experiments were performed. The T98G glioma cells $\left(2 \times 10^{5}\right)$ were treated with OA at $0,6.25,12.5,25,50,100$, and $200 \mathrm{nM}$ for 48 hours. The cells were trypsinized, centrifuged at $1500 \mathrm{rpm}$ for 10 minutes, and resuspended in $100 \mu \mathrm{l}$ of medium. After $20 \mu \mathrm{l}$ was removed and mixed with $80 \mu \mathrm{l}$ of Trypan blue (Gibco BRL, Grand Island, NY), $10 \mu \mathrm{l}$ of the mixture was removed to undergo counting with a hemacytometer. Experiments were performed in duplicate and then repeated. Glioma cells $\left(2 \times 10^{5}\right)$ were pretreated with the caspase-1 and -3 inhibitors Ac-YVAD-aomk (250 $\mu \mathrm{M})$ and DEVD-CHO $(250 \mu \mathrm{M})$ for 2 hours before exposure to $\mathrm{OA}(0,6.25,12.5$, and $25 \mathrm{nM})$. Cell counts were performed as previously described. Probability values were determined by applying the Student t-test.

\section{Apoptosis Assays}

Cells were grown on 100-mm plates and treated with OA $(25 \mathrm{nM})$ for 24 hours. Some cells were pretreated with caspase inhibitors as described previously. Treated cells were examined under light and fluorescent microscopy. First, the cells were washed in cold PBS, then $8 \mu$ of 100$\mu \mathrm{M}$ YO-PRO- 1 dye and $4 \mu \mathrm{l}$ of $1.5-\mathrm{mM}$ propidium iodide was added for each $500 \mu l$ of PBS. After incubation on ice for 15 minutes, the cells were washed in cold PBS and observed under a fluorescent microscope. Live cells show little or no fluorescence whereas apoptotic cells show green fluorescence. Loss of cell integrity indicating necrosis results in red fluorescence. ${ }^{10}$

\section{Immunoprecipitation and Kinase Assays}

Following treatment with $\mathrm{OA}$ for various times, cells were harvested using a buffer containing $50 \mathrm{mM}$ Tris- $\mathrm{HCl}$ (pH 8), $150 \mathrm{mM} \mathrm{NaCl}, 1 \%$ Triton X-100, $0.5 \%$ sodium deoxycholate, and supplemented with phosphatase and protease inhibitors: $5 \mathrm{mM}$ sodium fluoride, $1 \mathrm{mM}$ sodium orthovanadate, 4-(2-aminoethyl)-benzenesulfonyl fluoride hydrochlorine (ICN Biochemicals, Aurora, OH). After being lysed by repeated passages through an 18-gauge needle, the cell extracts were transferred to a microfuge tube and incubated on ice for 30 minutes. Cellular debris was removed from the soluble extracts by centrifugation at $12,000 \mathrm{G}$ for 15 minutes at $4^{\circ} \mathrm{C}$. The resulting lysates were precleared by incubation with protein A Sepharose (Pharmacia, Piscataway, NJ) for 1 hour at $4^{\circ} \mathrm{C}$. After determining the protein concentration in each lysate, protein $(50 \mu \mathrm{g})$ was incubated overnight on an orbital shaker at $4^{\circ} \mathrm{C}$ with $1 \mu \mathrm{g}$ of anti-ERK, anti-JNK, or anti-p38 antibody (Santa Cruz Biotechnology, Santa Cruz, CA). The immunocomplex was captured by adding protein A Sepharose $(25 \mu \mathrm{l})$ to the protein mixture and incubating for 2 hours at $4^{\circ} \mathrm{C}$. The beads were isolated by centrifugation at $2500 \mathrm{rpm}$ for 5 minutes, followed by two washes in $1 \mathrm{ml}$ of wash buffer (50 mM Tris- $\mathrm{HCl}[\mathrm{pH} 7])$ and one wash in $200 \mu \mathrm{l}$ of kinase buffer $(50 \mathrm{mM}$ Tris- $\mathrm{HCl}[\mathrm{pH}$ 7.4], $10 \mathrm{mM} \mathrm{MgCl}, 1 \mathrm{mM}$ dithiothreitol, and $1 \mathrm{mM}$ sodium fluoride). The final pellet was resuspended in kinase buffer $(30 \mu \mathrm{l})$ supplemented with $2 \mathrm{mM}$ ethyleneglycotetraacetic acid, $10 \mu \mathrm{Ci}\left[\gamma^{32} \mathrm{P}\right]$ adenosine triphosphate (Amersham, Arlington Heights, IL), and the appropriate substrate: myelin basic protein (ERK1), GST-c-Jun (JNK), or GST-ATF-2 (p38) (10 $\mu \mathrm{g})$ (Gibco BRL). Reactions were conducted for 25 minutes at $30^{\circ} \mathrm{C}$ to reduce background signal. The reaction was stopped by the ad- 
dition of a $4 \times$ concentrated sample buffer $(10 \mu \mathrm{l})$. The samples were boiled for 5 minutes and $20 \mu \mathrm{l}$ was loaded onto a precast sodium dodecyl sulfate-10\% Tris-Glycine gel (Novex, San Diego, CA). After size fractionation, protein was transferred onto polyvinylidene difluoride membrane by using the Mini-Cell II Blot Module (Novex). The phosphorylated substrate was visualized by autoradiography.

\section{Western Blot Analysis}

Cells were harvested as described previously. Prior to loading, the protein concentration of each cell lysate was determined using a protein assay kit (Bio-Rad, Hercules, CA) and then diluted to $1 \mathrm{mg} / \mathrm{ml}$ in PBS. Protein $(10 \mu \mathrm{g})$ was boiled in sodium dodecyl sulfate-polyacrylamide gel electrophoresis $4 \times$ concentrated sample buffer, size fractionated on a precast 10 to $20 \%$ Tris-glycine gradient gel (Novex), and transferred onto polyvinylidene difluoride membrane by using a Mini-Cell II Blot Module (Novex). All membranes were blocked with 5\% non-fat dry milk and then incubated with anti-Bax antibody (Santa Cruz Biotechnology). Peroxidase-conjugated goat anti-mouse (Calbiochem) was diluted (1:1000) prior to addition. Each incubation was conducted at room temperature for 1 hour and was followed by a 15 -minute wash $(10 \mathrm{mM}$ Tris- $\mathrm{HCl}$ [pH 7.5]), $100 \mathrm{mM} \mathrm{NaCl}$, and $0.1 \%$ Tween 20). Detection of bands was performed using the ECL system (Amersham).

\section{Electrophoretic Mobility Shift Assay}

The NFkB consensus oligonucleotide (Santa Cruz Biotechnology) was en labeled with $\left[\gamma^{32} \mathrm{P}\right]$ adenosine triphosphate and T4 polynucleotide kinase (New England Biolabs, Beverly, MA) and purified by G-50 Sephadex columns (Pharmacia). Whole-cell protein extracts (25 mg) from cells treated with $\mathrm{OA}(20 \mathrm{nM})$ for 36 hours were added to ${ }^{32} \mathrm{P}-\mathrm{NF} \kappa$ oligo $(\sim 20,000 \mathrm{cpm}, 0.2 \mathrm{ng})$ in a buffer containing $2 \mathrm{mg}$ poly(dI-dC) (Pharmacia), $10 \mathrm{mg}$ BSA, 10 $\mathrm{mM}$ Tris- $\mathrm{HCl}(\mathrm{pH} 7.5), 50 \mathrm{mM} \mathrm{NaCl}, 1 \mathrm{mM}$ dithiothreitol, $1 \mathrm{mM}$ ethyleneglycotetraacetic acid, and 5\% glycerol (total volume $40 \mathrm{ml}$ ). The DNA complexes were resolved on a $4 \%$ nondenaturing polyacrylamide gel containing 50 $\mathrm{mM}$ Tris, $0.38 \mathrm{M}$ glycine, and $2 \mathrm{mM}$ ethyleneglycotetraacetic acid, and run at $100 \mathrm{~V}$ for 3 hours at room temperature. The same procedure was followed for the supershift assay except $2 \mathrm{ml}$ of NFkB p65 (A)X antibody (Santa Cruz Biotechnology) was incubated with the whole-cell extract for 30 minutes at room temperature prior to adding the ${ }^{32} \mathrm{P}-\mathrm{NF} \kappa$ oligo and reaction buffer.

\section{RESULTS}

\section{Okadaic Acid-Induced Apoptotic Cell Death}

The T98G, U87, and A172 glioma cells were grown in 96-well microtiter plates and exposed to increasing concentrations of OA for 48 hours. Using the MTS assay, we found inhibition of proliferation in all three cell lines (IC50 20-25 nM) (Fig. 1). To confirm the MTS results, we performed cell counts on OA-treated cells. Cell death increased with OA dose and similar IC50s were obtained for the three cell lines (IC50 20-40 nM) (Fig. 2). Treatment of

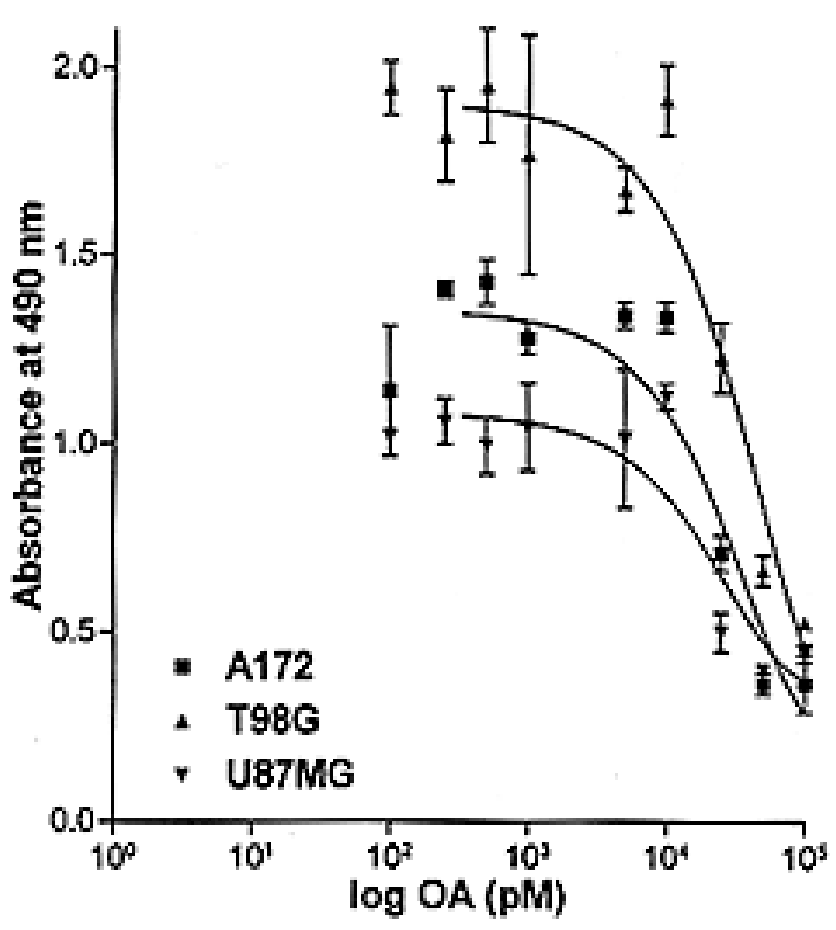

Fig. 1. Graph demonstrating OA inhibition of proliferation of glioma cell lines. The A172, T98G, and U87 cells were grown in 96-well microtiter plates and exposed to OA for 48 hours. Using the MTS assay, absorbance at $490 \mathrm{~nm}$ was measured and plotted against $\log$ OA concentration (pM). The SD is shown for each data point (eight). A four-parameter curve was fit to the data points and used to determine the IC50.

T98G cells with caspase- 1 and -3 inhibitors increased cell survival but did not prevent cell death (Fig. 3).

Subconfluent cultures of logarithmically growing T98G cells were treated with OA $(25 \mathrm{nM})$ for 24 hours and examined microscopically. The cells underwent apoptosis as indicated by a rounded, but intact cell appearance, condensed nuclear chromatin, and blebbing of the plasma membrane (Fig. 4 upper left and lower left). Fluorescent staining with YO-PRO confirmed apoptosis as evidenced by green fluorescence (Fig. 4 upper right and lower right). Some treated cells exhibited red fluorescence, indicating that some necrosis occurred as well (Fig. 4D).

\section{Okadaic Acid-Activates Protein Kinase Signal Transduction}

To determine the role of ERK, JNK, or p38 in OA-induced apoptosis we performed kinase assays on OA-treated T98G cells. Okadaic acid ( $20 \mathrm{nM})$ induced an increase in ERK activity that peaked at 12 hours and then declined (Fig. 5A). The JNK activity increased after 3 hours and was sustained at high levels for 48 hours (Fig. 5B). The p38 kinase activity was much less affected than MAPK or JNK (Fig. 5C).

\section{Okadaic Acid-Induced I $\kappa$ B Phosphorylation and NF $\kappa B$ Transduction}

To study phosphorylation of IкB, we used Western blot analysis with an antibody specific to the phosphorylated 

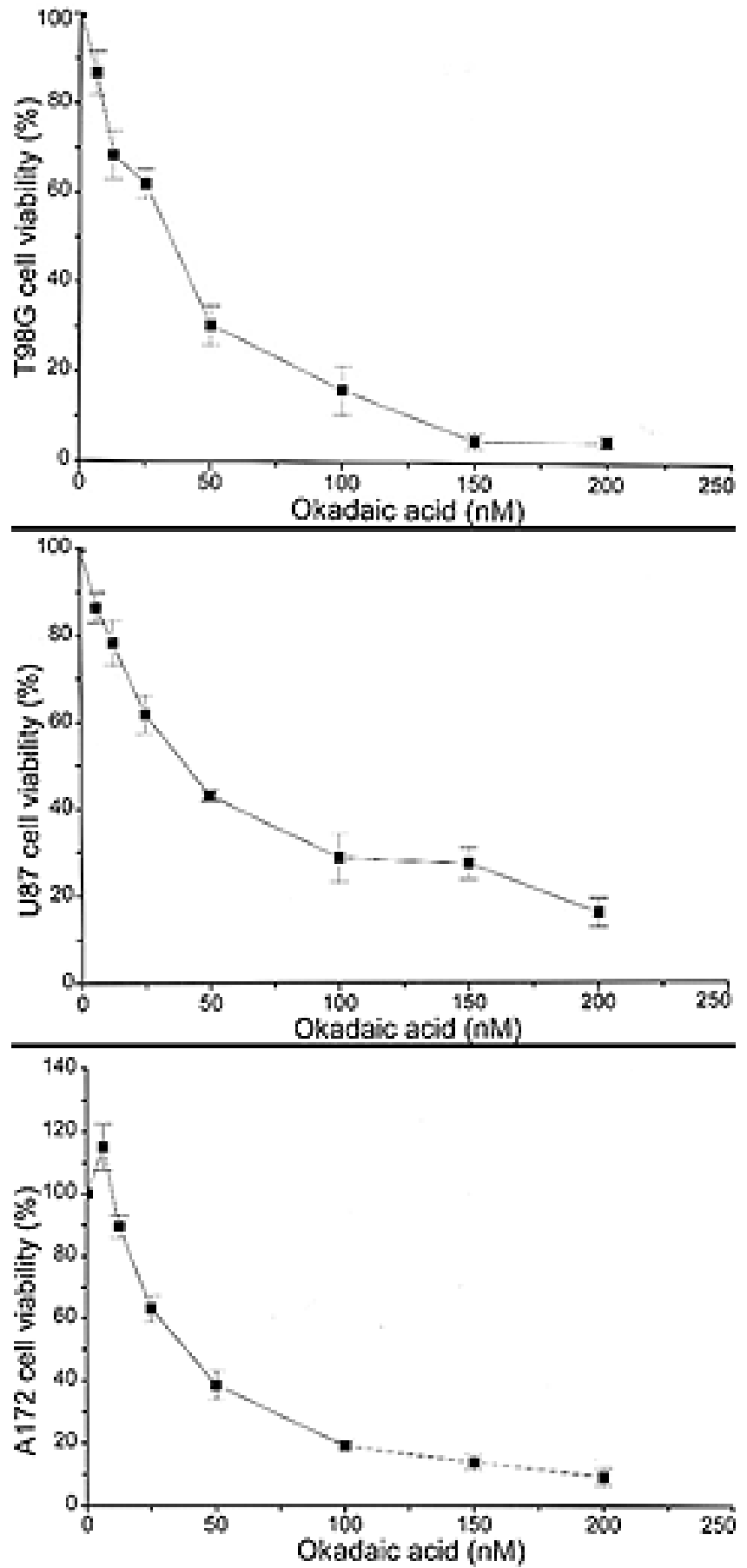

Fig. 2. Graphs showing the effect of OA on glioma cell proliferation (T98G [upper], U87 [center], and A172 [lower]) as determined by cell counts. Cells were treated with OA for 48 hours and then counted on a hemacytometer by using Trypan blue exclusion. Viability is expressed as a percentage of control (untreated) cells. The SD is shown for each data point.

form of IкB. An increase in phosphorylated IкB levels was noted after 6 hours of OA $(20 \mathrm{nM})$ treatment. The levels peaked at between 12 and 24 hours then quickly decreased, indicating IкB degradation (Fig. 6). Because IкB sequesters $\mathrm{NF} \kappa \mathrm{B}, \mathrm{OA}$-induced degradation of IкB

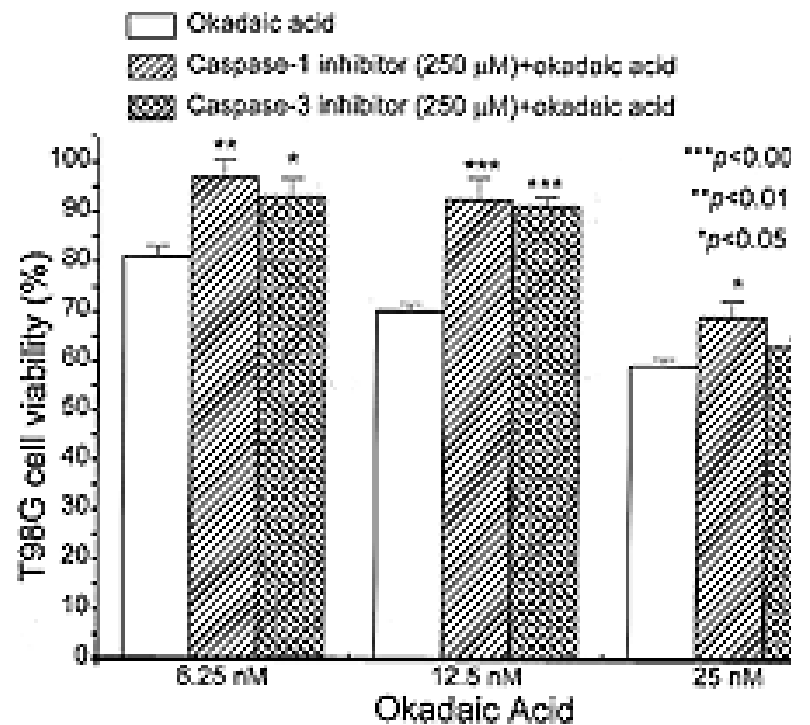

Fig. 3. Bar graph demonstrating the effect of caspase inhibitors on OA-induced cell death. The T98G cells were exposed to OA for 48 hours in the presence of caspase- 1 and -3 inhibitors. Cell counts were performed and expressed as a percentage of control (untreated) cells. The SDs and results of the Student t-test are shown.

should lead to an increase in NFkB binding. To test this, we performed an EMSA involving whole-cell protein extract and an oligonucleotide that contained the NFKB consensus site. Okadaic acid caused an increase in NFkB binding that was seen at 36 hours (Fig. 7). A supershifted band was shown in OA-treated cells when anti-NFкB antibody was added to EMSA, thus confirming specificity of NFKB binding (Fig. 7).

\section{Increases in Bax During Okadaic Acid-Induced Apoptosis}

Overexpression of the proapoptotic protein Bax induces apoptosis by inhibiting the activity of Bcl-2. We used Western blot analysis to determine protein levels of Bax in cells undergoing OA-induced apoptosis. In T98G cells, OA $(20 \mathrm{nM})$ increased Bax by 12 hours and peaked at 48 hours (Fig. 8). This late rise correlated with the time course observed in OA-induced morphology changes and DNA fragmentation.

\section{DISCUSSION}

The dual-signal theory of apoptosis was proposed to explain the role of the $c-m y c$ oncogene in apoptosis. Apoptosis and proliferation are believed to be competitive and simultaneous pathways that may have common cellular mediators. ${ }^{15}$ The ultimate fate of an individual cell depends on the intracellular balance between these pathways. We hypothesized that regulation of these two competing pathways occurs in part through the protein phosphorylation cascades within a cell. ${ }^{5}$ In this study we showed that 20 to $40 \mathrm{nM}$ of OA, a potent inhibitor of serine/threonine PP1 and PP2A, causes cell death, primarily by apoptosis in T98G cells. Our findings in three glioma cell lines are consistent with previous observations on the 

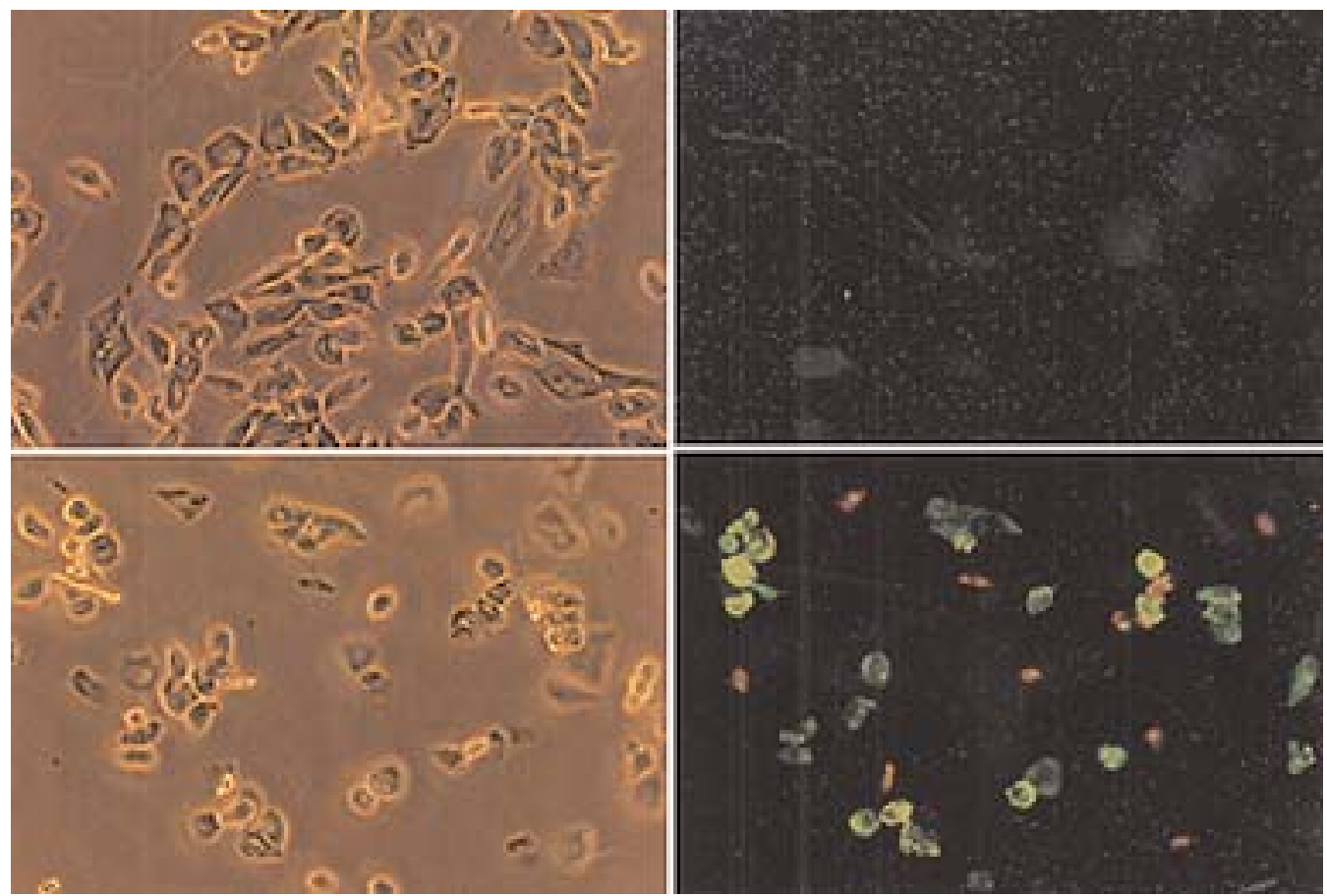

Fig. 4. Photographs demonstrating apoptosis by YO-PRO/propidium iodide staining. The T98G cells were treated with OA for 24 hours and then stained with YO-PRO and propidium iodide. Upper Left: Untreated cells seen under phase-contrast microscopy. Upper Right: Untreated cells under fluorescent microscopy (same field as upper left). Lower Left: The OA-treated cells (phase contrast). Lower Right: The OA-treated cells under fluorescent microscopy (same field as lower left). Green staining indicates apoptosis, and red indicates apoptosis. Original magnification $\times 16$.

effective OA concentration and the time course of DNA fragmentation in human breast carcinoma cells. ${ }^{4,21}$

The three major pathways that mediate stress and survival signals from the extracellular environment are characterized by their terminal kinase: ERK, JNK, or p38.

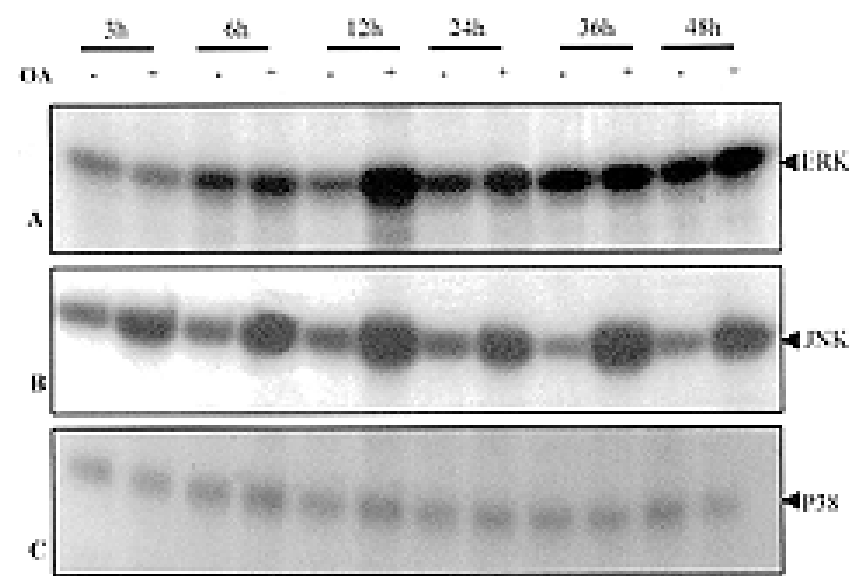

Fig. 5. Effect of OA on MAPK module kinases. The T98G cells were exposed to $20-\mathrm{nM}$ of $\mathrm{OA}$ for the time points indicated and then underwent protein extraction. An in vitro kinase assay was performed on immunoprecipitated protein and then resolved by gel electrophoresis. A: The ERK with myelin basic protein as substrate. B: The JNK with GST-c-Jun as substrate. C: The p38 with GST-ATF-2 as substrate. $\mathrm{h}=$ hours.
Using an in vitro kinase assay, we demonstrated an increase in ERK and JNK activity in T98G cells exposed to OA. This result is compatible with those reported previously by investigators who correlated JNK activity with apoptosis. ${ }^{1,24,25}$ Thymocyte apoptosis induced by VM26, a DNA-damaging agent, and radiation treatment has been correlated with increased JNK activity. ${ }^{39}$ Both ERK and p38 have also been implicated in apoptotic signaling., ${ }^{1,24,44}$ This is the first report, however, in which the sensitivity of these pathways to OA has been demonstrated in glioma cells. At present we can only correlate kinase activity with glioma apoptosis. Although directly observed in interleukin-3-induced apoptosis, further proof will require more direct manipulation of the ERK and $J N K$ genes in glioma cells. ${ }^{12}$

Using Western blot analysis and EMSA, we have shown that $\mathrm{OA}$ increases IкB phosphorylation and NFкB binding. Accumulation of phosphorylated I $\mathrm{B}$ is first seen

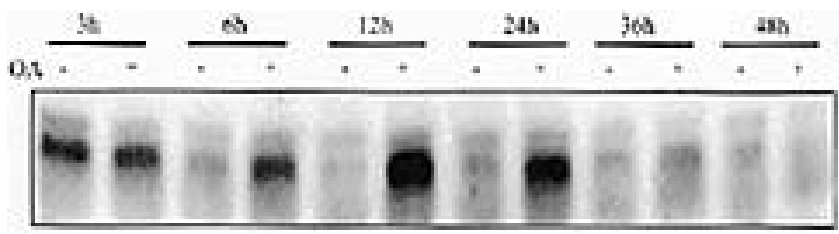

Fig. 6. Western blot analysis of $\mathrm{I} \kappa \mathrm{B}$ following OA treatment. The T98G cells were treated as shown and protein extracted at time points indicated. An antibody specific for phospho-IкB was used. 


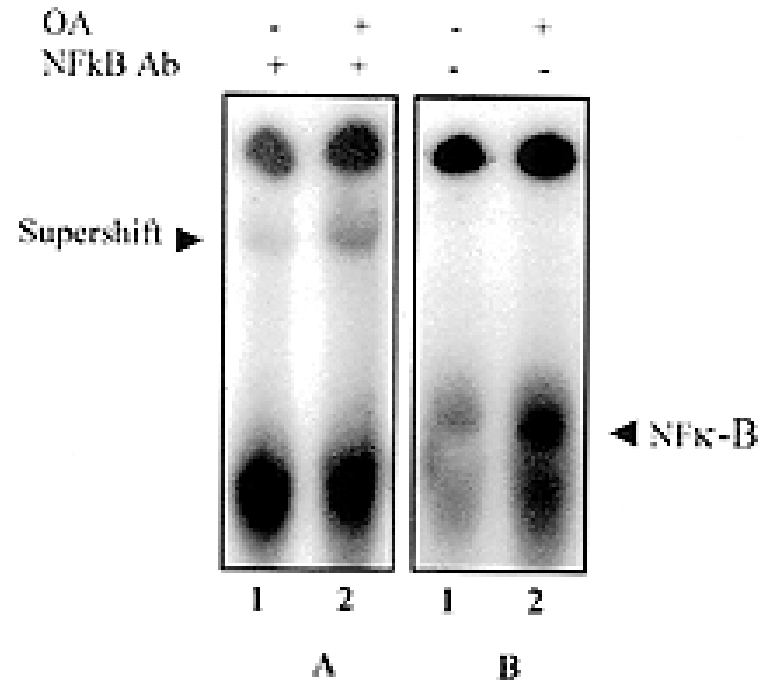

Fig. 7. Effect of OA on NFkB activation as determined by electrophoretic mobility shift assay. The T98G cells were treated with $20 \mathrm{nM}$ of OA for 36 hours. Protein extracts were probed with radiolabeled $\mathrm{NF} \kappa \mathrm{B}$ oligonucleotide and resolved on a denaturing gel. A: An anti-NFкB antibody was added to the reaction mixture to produce a supershifted band as indicated by the arrowhead. B: The position binding to the NFkB oligonucleotide is indicated by the arrowhead.

at 12 hours, followed by its degradation at 24 hours, and thus resulting in nuclear translocation of NFKB. As expected, we observed a significant increase in NFKB binding at 36 hours. Although the time frame for these events occurs after the activation of the MAPK, we have no proof that they directly phosphorylate ІкB. The authors of recent reports have indicated that $\mathrm{NF \kappa B}$ inhibits tumor necrosis factor-induced apoptosis. ${ }^{3,27,40,43}$ It is possible that the I $\mathrm{B}$ responses are epiphenomenona or it may be a cellular protective response against $\mathrm{OA}$.

The $\mathrm{Bcl}-2$ family of proteins is located in the mitochondrial membrane and protects against apoptosis by blocking caspase activity. ${ }^{41}$ The proapoptotic protein, Bax, heterodimerizes with Bcl-2, neutralizing its protective effect. ${ }^{32,48}$ Using Western blot analysis we observed a rise in Bax levels beginning at 12 hours and peaking at 36 hours. These results confirm recent observations that human breast carcinoma cells undergoing OA-induced apoptosis show an increase in Bax immunostaining at 36 to 48 hours. ${ }^{36}$ Phosphorylation and activation of caspases play an important role in the induction of apoptosis. ${ }^{18,26}$ To define further the involvement of caspases in OA-induced apoptosis, we treated T98G cells with a caspase-1 and -3 inhibitor. Both caspase inhibitors improved cell survival following OA treatment but did not eliminate all cell death. Although caspases are recognized to be an important mediator of apoptosis, OA may also trigger cell death by necrosis through noncaspase pathways as seen in other systems. ${ }^{19,22}$

\section{CONCLUSIONS}

In this study we described a potential signaling pathway for OA-induced apoptosis in glioma cells. Critical pro-

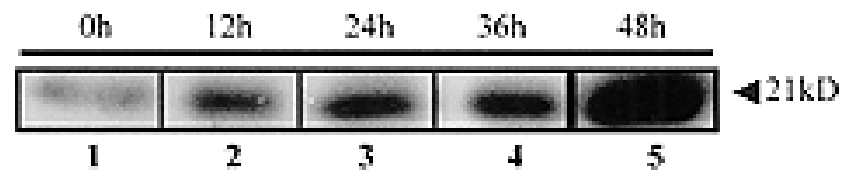

Fig. 8. Effect of OA on Bax expression. The T98G cells were treated with $20 \mathrm{nM}$ OA for the times indicated and then underwent Western blot analysis in which an anti-Bax antibody was used.

teins along this pathway include JNK, ERK, NFKB, and Bax. Because our study has focused on a single cell line, we cannot generalize these results to all glioma cells. Further studies of these signaling pathways triggered by OA may provide new targets for brain tumor therapies.

\section{References}

1. Avdi NJ, Malcolm KC, Nick JA, et al: A role for protein phosphatase-2A in p38 mitogen-activated protein kinase-mediated regulation of the c-Jun $\mathrm{NH}(2)$-terminal kinase pathway in human neutrophils. J Biol Chem 277:40687-40696, 2002

2. Baeuerle PA: The inducible transcription activator NF-kappa B: regulation by distinct protein subunits. Biochim Biophys Acta 1072:63-80, 1991

3. Beg AA, Baltimore D: An essential role for NF-kappaB in preventing TNF-alpha-induced cell death. Science 274:782-784, 1996

4. Boe R, Gjertsen BT, Vintermyr OK, et al: The protein phosphatase inhibitor okadaic acid induces morphological changes typical of apoptosis in mammalian cells. Exp Cell Res 195: 237-246, 1991

5. Chalfant CE, Rathman K, Pinkerman RL, et al: De novo ceramide regulates the alternative splicing of caspase 9 and $\mathrm{Bcl}-\mathrm{x}$ in A549 lung adenocarcinoma cells. Dependence on protein phosphatase-1. J Biol Chem 277:12587-12595, 2002

6. Chen Z, Naito M, Mashima T, et al: Activation of actin-cleavable interleukin 1beta-converting enzyme (ICE) family protease CPP-32 during chemotherapeutic agent-induced apoptosis in ovarian carcinoma cells. Cancer Res 56:5224-5229, 1996

7. Chin LS, Murray SF, Doherty PF, et al: K252a induces cell cycle arrest and apoptosis by inhibiting $\mathrm{Cdc} 2$ and $\mathrm{Cdc} 25 \mathrm{c}$. Cancer Invest 17:391-395, 1999

8. Chin LS, Murray SF, Harter DH, et al: Sodium vanadate inhibits apoptosis in malignant glioma cells: a role for Akt/PKB. J Biomed Sci 6:213-218, 1999

9. Chin LS, Murray SF, Zitnay KM, et al: K252a inhibits proliferation of glioma cells by blocking platelet-derived growth factor signal transduction. Clin Cancer Res 3:771-776, 1997

10. Daly JM, Jannot CB, Beerli RR, et al: Neu differentiation factor induces ErbB2 down-regulation and apoptosis of ErbB2overexpressing breast tumor cells. Cancer Res 57:3804-3811, 1997

11. DeJesus V, Rios I, Davis C, et al: Induction of apoptosis in human replicative senescent fibroblasts. Exp Cell Res 274:92-99, 2002

12. Deng X, Xiao L, Lang W, et al: Novel role for JNK as a stressactivated Bcl2 kinase. J Biol Chem 276:23681-23688, 2001

13. DiDonato JA, Hayakawa M, Rothwarf DM, et al: A cytokineresponsive IkappaB kinase that activates the transcription factor NF-kappaB. Nature 388:548-554, 1997

14. Elegbede JA, Hayes K, Schell K, et al: Induction of apoptosis and inhibition of papilloma formation may signal a new role for okadaic acid. Life Sci 71:421-436, 2002

15. Evan GI, Wyllie AH, Gilbert CS, et al: Induction of apoptosis in fibroblasts by c-myc protein. Cell 69:119-128, 1992 
16. Frankel SK, Van Linden AA, Riches DW: Heterogeneity in the phosphorylation of human death receptors by $\mathrm{p} 42$ (mapk/erk2). Biochem Biophys Res Commun 288:313-320, 2001

17. Goto K, Fukuda J, Haneji T: Okadaic acid stimulates apoptosis through expression of Fas receptor and Fas ligand in human oral squamous carcinoma cells. Oral Oncol 38:16-22, 2002

18. Hermann R, Hensel F, Muller EC, et al: Deactivation of regulatory proteins hnRNP A1 and A2 during SC-1 induced apoptosis. Hum Antibodies 10:83-90, 2001

19. Kang HS, Choi I: Protein phosphatase 2A modulates the proliferation of human multiple myeloma cells via regulation of the production of reactive oxygen intermediates and anti-apoptotic factors. Cell Immunol 213:34-44, 2001

20. Karin M, Hunter T: Transcriptional control by protein phosphorylation: signal transmission from the cell surface to the nucleus. Curr Biol 5:747-757, 1995

21. Kiguchi K, Glesne D, Chubb CH, et al: Differential induction of apoptosis in human breast tumor cells by okadaic acid and related inhibitors of protein phosphatases 1 and 2A. Cell Growth Differ 5:995-1004, 1994

22. Kolb TM, Chang SH, Davis MA: Biochemical and morphological events during okadaic acid-induced apoptosis of Tsc2-null ERC-18 cell line. Toxicol Pathol 30:235-246, 2002

23. Kondo S, Barna BP, Morimura T, et al: Interleukin-1 beta-converting enzyme mediates cisplatin-induced apoptosis in malignant glioma cells. Cancer Res 55:6166-6171, 1995

24. Kyriakis JM, Avruch J: Sounding the alarm: protein kinase cascades activated by stress and inflammation. J Biol Chem 271: 24313-24316, 1996

25. Larsen AK, Moller MT, Blankson H, et al: Naringin-sensitive phosphorylation of plectin, a cytoskeletal cross-linking protein, in isolated rat hepatocytes. J Biol Chem 277:34826-34835, 2002

26. Li DW, Xiang H, Mao YW, et al: Caspase-3 is actively involved in okadaic acid-induced lens epithelial cell apoptosis. Exp Cell Res 266:279-291, 2001

27. Liu ZG, Hsu H, Goeddel DV, et al: Dissection of TNF receptor 1 effector functions: JNK activation is not linked to apoptosis while NF-kappaB activation prevents cell death. Cell 87: 565-576, 1996

28. Long X, Wu G, Gaa ST, et al: Inhibition of protein phosphatase1 is linked to phosphorylation of p53 and apoptosis. Apoptosis 7:31-39, 2002

29. Morimoto Y, Ohba T, Kobayashi S, et al: The protein phosphatase inhibitors okadaic acid and calyculin A induce apoptosis in human osteoblastic cells. Exp Cell Res 230:181-186, 1997

30. Mukhopadhyay A, Shishodia S, Suttles J, et al: Ectopic expression of protein-tyrosine kinase Bcr-Abl suppresses tumor necrosis factor (TNF)-induced NF-kappa B activation and IkappaBalpha phosphorylation. Relationship with down-regulation of TNF receptors. J Biol Chem 277:30622-30628, 2002

31. Oltvai ZN, Korsmeyer SJ: Checkpoints of dueling dimers foil death wishes. Cell 79:189-192, 1994

32. Oltvai ZN, Milliman CL, Korsmeyer SJ: Bcl-2 heterodimerizes in vivo with a conserved homolog, Bax, that accelerates programmed cell death. Cell 74:609-619, 1993

33. Rossini GP, Sgarbi N, Malaguti C: The toxic responses induced by okadaic acid involve processing of multiple caspase isoforms. Toxicon 39:763-770, 2001

34. Schmidt KN, Traenckner EB, Meier B, et al: Induction of oxidative stress by okadaic acid is required for activation of transcription factor NF-kappa B. J Biol Chem 270:27136-27142, 1995
35. Schonthal A: Okadaic acid-a valuable new tool for the study of signal transduction and cell cycle regulation? New Biol 4:16-21, 1992

36. Sheikh MS, Garcia M, Zhan Q, et al: Cell cycle-independent regulation of $\mathrm{p} 21 \mathrm{Waf} 1 / \mathrm{Cip} 1$ and retinoblastoma protein during okadaic acid-induced apoptosis is coupled with induction of Bax protein in human breast carcinoma cells. Cell Growth Differ 7:1599-1607, 1996

37. Suganuma M, Fujiki H, Suguri $H$, et al: Okadaic acid: an additional non-phorbol-12-tetradecanoate-13-acetate-type tumor promoter. Proc Natl Acad Sci USA 85:1768-1771, 1988

38. Tanigawa Y, Yoshihara K, Koide SS: Presence of Ca $2+, \mathrm{Mg}$ 2+-dependent endonuclease stimulating factor in rat liver and testis nuclei. Biochem Biophys Res Commun 59:935-940, 1974

39. Testolin L, Carson C, Wang Y, et al: Jun and JNK kinase are activated in thymocytes in response to VM26 and radiation but not glucocorticoids. Exp Cell Res 230:220-232, 1997

40. Van Antwerp DJ, Martin SJ, Kafri T, et al: Suppression of TNFalpha-induced apoptosis by NF-kappaB. Science 274:787-789, 1996

41. Vaux DL, Weissman IL, Kim SK: Prevention of programmed cell death in Caenorhabditis elegans by human bcl-2. Science 258:1955-1957, 1992

42. Verma IM, Stevenson JK, Schwarz EM, et al: Rel/NF-kappa B/I kappa B family: intimate tales of association and dissociation. Genes Dev 9:2723-2735, 1995

43. Wang CY, Mayo MW, Baldwin AS Jr: TNF- and cancer therapy-induced apoptosis: potentiation by inhibition of NF-kappaB. Science 274:784-787, 1996

44. Watabe M, Masuda Y, Nakajo S, et al: The cooperative interaction of two different signaling pathways in response to bufalin induces apoptosis in human leukemia U937 cells. J Biol Chem 271:14067-14072, 1996

45. Xia Z, Dickens M, Raingeaud J, et al: Opposing effects of ERK and JNK-p38 MAP kinases on apoptosis. Science 270: 1326-1331, 1995

46. Yang J, Fan GH, Wadzinski BE, et al: Protein phosphatase 2A interacts with and directly dephosphorylates RelA. J Biol Chem 276:47828-47833, 2001

47. Yellaturu CR, Bhanoori M, Neeli I, et al: N-ethylmaleimide inhibits platelet-derived growth factor BB-stimulated Akt phosphorylation via activation of protein phosphatase 2A. J Biol Chem 277:40148-40155, 2002

48. Yin C, Knudson CM, Korsmeyer SJ, et al: Bax suppresses tumorigenesis and stimulates apoptosis in vivo. Nature 385: 637-640, 1997

49. Yin XM, Oltvai ZN, Korsmeyer SJ: BH1 and BH2 domains of Bcl-2 are required for inhibition of apoptosis and heterodimerization with Bax. Nature 369:321-323, 1994

50. Yu JS, Sena-Esteves M, Paulus W, et al: Retroviral delivery and tetracycline-dependent expression of IL-1beta-converting enzyme (ICE) in a rat glioma model provides controlled induction of apoptotic death in tumor cells. Cancer Res 56: 5423-5427, 1996

51. Yuan J, Shaham S, Ledoux S, et al: The C. elegans cell death gene ced-3 encodes a protein similar to mammalian interleukin1 beta-converting enzyme. Cell 75:641-652, 1993

Manuscript received October 8, 2002.

Accepted in final form January 22, 2003.

Address reprint requests to: Lawrence S. Chin, M.D., Department of Neurosurgery, 22 South Greene Street, Suite S-12-D, Baltimore, Maryland 21201. email: lchin@smail.umaryland.edu. 